\title{
Context-dependant survival of the invasive seaweed Codium fragile ssp. tomentosoides in kelp bed and urchin barren habitats off Nova Scotia
}

\author{
Devin A. Lyons*, Robert E. Scheibling \\ Department of Biology, Dalhousie University, Halifax, Nova Scotia B3H 4J1, Canada
}

\begin{abstract}
This study examines the fate of the invasive alga Codium fragile ssp. tomentosoides at destructive grazing fronts of the green sea urchin Strongylocentrotus droebachiensis along the margins of algal beds and in barren grounds formed in the wake of these fronts. We monitored the first reported encounter between an urchin front and an algal bed containing $C$. fragile, and conducted a series of manipulative experiments at a grazing front and in a barrens habitat. Urchin density had a significant effect on survival of $C$. fragile. At low densities, urchin fronts were more likely to bypass the invasive alga, though urchins following behind the front eventually consumed most individuals. Urchins' preferred food, laminarian kelps, affected the survival time of $C$. fragile by slowing the forward propagation of the front, but did not divert urchins from consuming $C$. fragile. The presence of dense stands of the unpalatable macroalgae Desmarestia viridis and periods of high water temperature and wave action appeared to facilitate the survival of $C$. fragile by affecting urchin foraging behaviour. Our results suggest that, although urchins have the potential to exert strong control over populations of $C$. fragile, the outcome of interactions between the 2 species is likely to depend on their biotic and abiotic context.
\end{abstract}

KEY WORDS: Codium fragile ssp. tomentosoides · Strongylocentrotus droebachiensis · Herbivory · Invasion · Invasive seaweed

\section{INTRODUCTION}

Understanding why some introduced organisms become abundant and widespread in their new environments is a central theme in the study of biological invasions. One of the most widely cited explanations for the success of invasive plants is the enemy release hypothesis: invasive species are released from herbivores in their native range and escape herbivores that are not adapted to feed on them in the introduced range (Keane \& Crawley 2002). However, the generality of the enemy release hypothesis has been questioned (Maron \& Vila 2001, Colautti et al. 2004). For instance, it is intuitive that exotic plants might escape specialist herbivores in their new range. Why they might be released from generalist herbivores is less obvious. Unfortunately, the influence of generalist herbivores has often been overlooked (Keane \& Crawley 2002, Parker et al. 2006).
Recent studies have suggested that native herbivores may actually have a greater impact on exotic than native plants (Parker \& Hay 2005, Parker et al. 2006). This does not appear to be the case for interactions between native herbivores, the invasive alga Codium fragile ssp. tomentosoides (Codium fragile hereafter), and native macroalgae in the Northwest Atlantic. Laboratory and caging studies have shown that herbivores such as the snail Lacuna vincta and the sea urchin Strongylocentrotus droebachiensis preferentially consume algal turfs and laminarian kelps, while largely ignoring $C$. fragile when a choice of foods is available (Scheibling \& Anthony 2001, Levin et al. 2002, Sumi \& Scheibling 2005). The low preference rank of $C$. fragile may be due to its production of dimethylsulfoniopropionate, the precursor molecule in an activated anti-grazing defence (Van Alstyne et al. 2001, Lyons et al. 2007). However, the response of 
S. droebachiensis appears to be context dependant. Under single diet conditions, these urchins consume significantly more $C$. fragile than their preferred food, the kelp Saccharina longicruris (formerly Laminaria longicruris). Moreover, urchins fed a single diet of $S$. longicruris for several months exhibit a brief reversal of preference, from $S$. longicruris to $C$. fragile (Lyons \& Scheibling 2007).

Interactions between wild populations of Strongylocentrotus droebachiensis and Codium fragile are yet to be elucidated. In Nova Scotia, C. fragile began to dominate large sections of the rocky subtidal zone in the late 1990s and early 2000s, following the defoliation of native kelps by another exotic species, the epiphytic bryozoan Membranipora membranacea (Chapman et al. 2002, Scheibling \& Gagnon 2006). During this period, shallow-water urchin populations remained low following disease-induced mass mortalities in 1995 and 1999 (Scheibling \& Hennigar 1997, Miller \& Nolan 2000). Based on the limited, mostly laboratory-based studies that have been conducted to date, it has been suggested that herbivore preferences will reinforce the shift from kelp dominance to $C$. fragile dominance, except when destructively grazing urchins are likely to consume all erect macroalgae (Scheibling \& Anthony 2001, Levin et al. 2002, Sumi \& Scheibling 2005). Until recently, marked reductions of shallow-water urchin populations due to disease in Nova Scotia (Scheibling \& Hennigar 1997, Miller \& Nolan 2000) and over-fishing in the Gulf of Maine (Harris \& Tyrrell 2001) have precluded tests of these predictions.

The outcome of interactions between Codium fragile and Strongylocentrotus droebachiensis can have important consequences for the structure and dynamics of the rocky subtidal ecosystem. If urchins destructively graze $C$. fragile, they could exert a controlling influence on the establishment and spread of the invasive alga. However, if $C$. fragile escapes urchin grazing, this could disrupt the historical alternation between macroalgal- and urchindominated states of the system (Miller 1985, Harris \& Tyrrell 2001). In the present study, we examine the fate of $C$. fragile as urchins form grazing fronts along the offshore margins of algal beds and create barrens as they migrate from deep-water refugia (Scheibling et al. 1999). We monitored naturally occurring $C$. fragile in a mixed algal stand, and experimentally transplanted thalli in a kelp bed and adjacent urchin barren, to examine effects of urchin den- sity and algal composition and abundance on survival of the invasive alga. In addition, we compared survival of $C$. fragile to that of both a preferred (Saccharina longicruris) and an unpalatable (Desmarestia viridis) algal species in a series of transplant experiments in a barrens habitat under different seasonal conditions (temperature, wave action) known to affect urchin activity.

\section{MATERIALS AND METHODS}

Survival at a grazing front. The advance of a grazing front of Strongylocentrotus droebachiensis and resulting changes in the cover of erect macroalgae were monitored between 30 April and 18 October 2003 at Birchy Head (Fig. 1a; $44^{\circ} 35^{\prime} \mathrm{N}, 64^{\circ} 03^{\prime} \mathrm{W}$ ), Nova Scotia, Canada. The site is located within St. Margaret's Bay, a large semi-protected embayment. The substratum consists of a gently sloping field of granitic boulders of varying sizes. At a depth of about 8 to $10 \mathrm{~m}$ below chart datum the boulders become sparser and are separated by patches of sand. At the start of the study, an algal bed consisting of a high cover of turf-

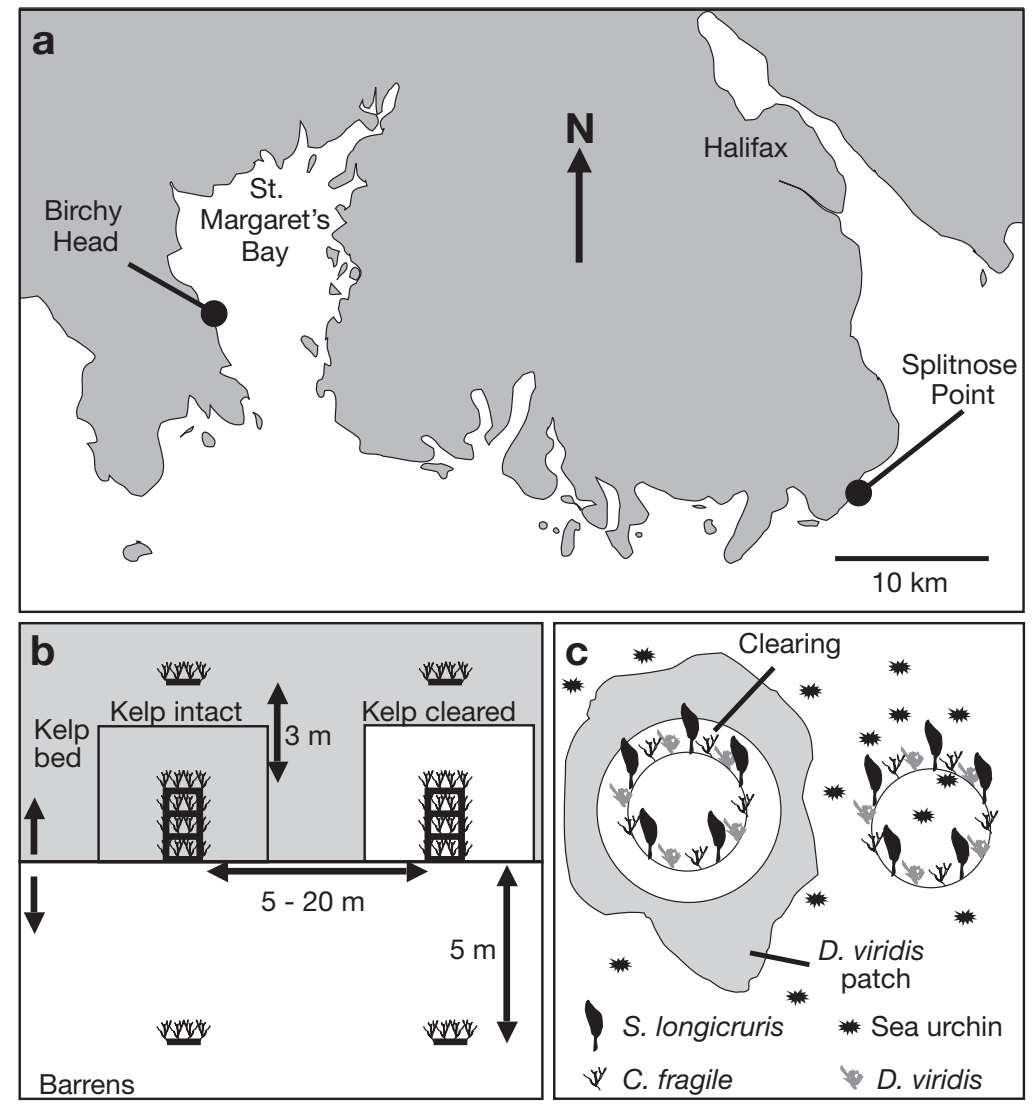

Fig. 1. (a) Atlantic coast of Nova Scotia showing location of study sites at Birchy Head and Splitnose Point. (b) Cleared and uncleared kelp treatment plots in Expt 1 and (c) protected and unprotected rings in Expt 2 
forming algae extended to a depth of $7 \mathrm{~m}$. In the shallows (2 to $4 \mathrm{~m}$ ), Codium fragile was the most abundant large macrophyte, but cover of $C$. fragile decreased with depth and Desmarestia viridis became increasingly abundant. Detached thalli (drift) of $C$. fragile were abundant in depressions between boulders. The kelp Saccharina longicruris was sparsely distributed throughout the algal bed. A front of actively grazing urchins (mean \pm SD test diameter: $4.4 \pm 0.6 \mathrm{~cm}, \mathrm{n}=28$ ) was found at the lower margin of the algal bed, below which scattered individuals and small aggregations occurred on the boulders surrounded by sand. Few erect macroalgae occurred behind the urchin front, with the exception of $D$. viridis and occasional thalli of $C$. fragile growing on the boulders or deposited as drift algae.

On 30 April and 16 June, 2003, urchin density at the front was measured in random frame-grabs $(n=20)$ taken from a $60 \mathrm{~m}$ video transect along the interface between the algal bed and barrens, using an object of known length for scale to calculate the area within each frame $\left(0.25 \mathrm{~m}^{2}\right)$. On 18 October, following a mass mortality of urchins, density was measured by counting urchins in $0.25 \mathrm{~m}^{2}$ quadrats $(\mathrm{n}=36)$ placed at $\sim 2 \mathrm{~m}$ intervals along the same section of seabed. On 16 June, the cover of 4 types of erect macroalgae (Saccharina longicruris, Desmarestia viridis, Codium fragile and turf-forming algae) and bare rock (denuded of erect algae but covered with encrusting coralline algae, Lithothamnion glaciale and Phymatolithon lenormandii) was recorded in frame grabs $\left(0.73 \mathrm{~m}^{2}\right.$, $\mathrm{n}=20$ ) taken from 2 additional video transects extending parallel to the interface (and urchin front) and 1 to $2 \mathrm{~m}$ to either side of it. Percentage cover of each algal type and bare rock was measured using image analysis software (ImageJ v. 1.37, Wayne Rasband, National Institutes of Health) and compared between algal bed and barrens habitats using $t$-tests.

Expt 1: Transplantation to a high-density front. A grazing front of Strongylocentrotus droebachiensis did not re-form following the October 2003 mass mortality at Birchy Head, or at other sites where Codium fragile was locally abundant. (Urchins remained rare to absent at these sites in December 2007.) Therefore, we designed a transplant experiment to test previous predictions that an actively grazing front would consume C. fragile (Scheibling \& Anthony 2001, Sumi \& Scheibling 2005) and to determine how urchin density and the presence of kelps influence the survival of C. fragile. We predicted that urchins would bypass $C$. fragile in favour of consuming kelp if it was present, but would consume $C$. fragile in the absence of kelp. Based on our observations at Birchy Head, we also predicted that the grazing front might bypass $C$. fragile even in the absence of kelp at low urchin densities, but consume $C$. fragile at higher densities.
The experiment was conducted at Splitnose Point

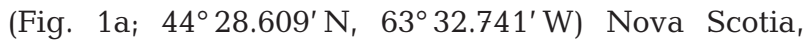
Canada, a site where urchins were abundant but density varied greatly along the front. The site consists of a series of gently sloping granitic ledges that grade to sand at a depth of $35 \mathrm{~m}$ below chart datum, and it is exposed to waves from the south and east. In July 2005, a luxuriant kelp bed (mainly Laminaria digitata and Saccharina longicruris) extended from the lower intertidal zone to a depth of $12 \mathrm{~m}$, where it was being destructively grazed by a dense front of Strongylocentrotus droebachiensis (mean \pm SD test diameter: $5.6 \pm$ $0.9 \mathrm{~cm}, \mathrm{n}=28$ ). Below $12 \mathrm{~m}$, the rock ledges were covered by encrusting coralline algae, with patches of Desmarestia viridis ranging in size from 1 to $100 \mathrm{~m}^{2}$. Codium fragile was absent at this site; the nearest location where the invasive alga had been recorded in 2000 was $1.5 \mathrm{~km}$ to the northeast (Chapman et al. 2002). During the experiment, water temperature at $12 \mathrm{~m}$ was recorded using a temperature logger (StowAway TidbiT Temp Logger, Onset Computer Corporation) installed at the site and significant wave height (SWH) data were obtained from a meteorological buoy (www.meds-sdmm.dfo-mpo.gc.ca) located at the mouth of Halifax Harbour (Buoy ID C44258, 44 $34^{\circ} \mathrm{N}$, $\left.63^{\circ} 24^{\prime} \mathrm{W}\right) 11.9 \mathrm{~km}$ from our study site. Data from this buoy were strongly correlated with significant wave heights measured at Splitnose Point (Lauzon-Guay \& Scheibling 2007a).

The experimental layout consisted of 6 plots positioned at 5 to $20 \mathrm{~m}$ intervals along the edge of the kelp bed in advance of the urchin front on 19 July 2005. Complete thalli of Codium fragile, collected on 17 July at a site in St. Margaret's Bay (The Lodge; $44^{\circ} 33^{\prime} \mathrm{N}$, $64^{\circ} 01^{\prime} \mathrm{W}$ ) and maintained in flow-through seawater tanks in the laboratory, were transplanted by attaching individual thalli to a chain-grid. The chain served as an anchor for the transplants that conformed to the bottom topography and that could be readily insinuated between kelp thalli. Each grid consisted of two $2 \mathrm{~m}$ lengths of chain extending perpendicular to the edge of the kelp bed (Fig. 1b). These lengths were connected by a series of 4 parallel $1 \mathrm{~m}$ lengths of chain spaced $67 \mathrm{~cm}$ apart $(0,67,123$ and $200 \mathrm{~cm}$ from the front). To each of these, a $1 \mathrm{~m}$ length of polypropylene rope with 4 thalli of $C$. fragile, spaced $25 \mathrm{~cm}$ apart, was attached using cable ties. C. fragile was attached to polypropylene rope by threading the basal end of the stipe between the strands of the rope. To test the effects of the kelp bed on survival of $C$. fragile, all kelps within the grid and a $2 \mathrm{~m}$ buffer around the grid were removed in 3 plots, randomly selected from the 6 experimental plots. The number of kelps of each species in each of the uncleared grids was counted. At each grid location, an additional set of 4 thalli of 
C. fragile, similarly attached to a length of chain, was placed $3 \mathrm{~m}$ further into the algal bed than the grid ( $\sim 5 \mathrm{~m}$ from the front) as a control for the loss of C. fragile due to factors other than grazing by urchins (which were rare in the kelp bed). Another set of 4 thalli was placed in the barrens $5 \mathrm{~m}$ from the edge of the kelp bed (and the chain grid) in each plot.

The experiment was monitored at approximately $4 \mathrm{~d}$ intervals (24 and 28 July; 1, 5, 9, 14 and 18 August) and was terminated on 18 August, before the grazing front had reached any of the control thalli in the kelp bed. On each sampling date, the presence or absence of each transplant of Codium fragile was recorded. An individual was considered lost if the stipe (below the first bifurcation) had been chewed through or if the thallus was entirely missing. Each plot was video recorded to measure urchin density and the position of the front relative to the grid. Urchin density in the grid at each plot was measured in frame grabs taken at the leading edge of the front, using an object of known length to calculate the frame area $\left(0.2 \mathrm{~m}^{2}\right.$, on average) The number of urchins within $30 \mathrm{~cm}$ of the barrens line within each plot was recorded on 24 July, $5 \mathrm{~d}$ after the start of the experiment. The number of urchins close to the barrens lines associated with cleared and uncleared plots were compared using a $t$-test. The data were log transformed prior to analysis to meet the assumption of homogeneity of variance. We used linear regression to examine the relationship between the number of urchins around each of the 6 lines and the time it took for $C$. fragile thalli to disappear.

The percentage of Codium fragile surviving in cleared and intact canopy treatments was compared using repeated-measures analysis of variance (RMANOVA). Separate analyses were conducted for transplants placed in the path of the front (in the chain grids) and those in the barrens (in the single chain lines). Greenhouse-Geisser adjusted degrees of freedom were used when the Mauchly criterion test indicated that the sphericity assumption was not met $(\mathrm{p}<$ 0.05). These analyses simply examined the effect of clearing kelp, but did not account for variability in urchin density, kelp density in uncleared plots, or the distance between thalli and the urchin front at the start of the experiment. To examine the influence of these factors on survival of individual thalli of C. fragile, we used a Cox proportional hazards model. This semiparametric survival analysis technique is advantageous in that it does not assume a particular distribution of survival times (Allison 1995). Survival analysis was conducted using the PHREG procedure in SAS v. 9.1.3. Ties were handled using the EXACT method, which is more appropriate than other methods when there is a true but unknown ordering of the tied event times (Allison 1995). Our full model included mean urchin density at the plot, distance of individual thalli from the grazing front at the start of the experiment, density of kelp around the thalli, and all possible interactions between these variables. We then selected variables for inclusion in the model using a step-down procedure in which nested models were compared with likelihood ratio tests (Parmar \& Machin 1995).

The density of urchins and kelp may influence the survival of Codium fragile by determining the rate of front advance (and hence encounter rate with $C$. fragile) or by affecting the likelihood that $C$. fragile is consumed when encountered. We used linear regression to examine the relationship between percentage survival of transplants (for at least 1 sampling interval after the front had passed) and both kelp and urchin density in the plots.

Expt 2: Survival relative to native algae in a barren. We compared the survival of Codium fragile to native macroalgae, which were either attractive to urchins and preferred as food (Saccharina longicruris) or unattractive and unpalatable (Desmarestia viridis), by transplanting thalli of each species into the barrens, at least $20 \mathrm{~m}$ from the actively grazing front at Splitnose Point. We predicted that the kelp S. longicruris would be consumed quickly, while $D$. viridis would be largely unaffected by urchin grazing. We expected that $C$. fragile would eventually be consumed, once the kelp was gone.

Transplants were set out using the chain and rope system described above, except that thalli were arranged on $2.5 \mathrm{~m}$ diameter rings, rather than grids (Fig. 1c). Individuals of the 3 algal species were spaced $0.5 \mathrm{~m}$ apart around the $8 \mathrm{~m}$ circumference in an alternating fashion, such that 5 ind. of each species were placed on each ring. Codium fragile was collected and attached as described for Expt 1. Saccharina longicruris and Desmarestia viridis were collected at Splitnose Point, and deployed on the day of collection. S. longicruris was brought to the surface and attached, as described for $C$. fragile, on our research vessel. $D$. viridis was attached underwater to prevent the rupture of vesicles containing sulphuric acid and subsequent disintegration of the alga. Experimental thalli of each species were selected (or trimmed) to be approximately 25 to $35 \mathrm{~cm}$ in length. The experiment was repeated during 3 periods: summer 2005 (twice, 20 July to 1 August and 1 to 18 August, $n=10$ ), fall 2005 (24 August to 5 October, $\mathrm{n}=20$ ) and spring 2007 (8 June to 3 July, $\mathrm{n}=20$ ). Prior to each run, urchin density in the experimental area was measured in $0.25 \mathrm{~m}^{2}$ quadrats ( $n=30$ to 46 ) haphazardly placed on the seabed around each ring. Water temperature and SWH data were collected as described in 'Materials and methods - Expt 1'. Each experimental run was monitored at $\sim 4 \mathrm{~d}$ intervals, except for an initial sampling in spring, $24 \mathrm{~h}$ after the start of the experiment. 
For each period, the survival functions of the 3 species were estimated using the Kaplan-Meier method and compared with log-rank tests (Parmar \& Machin 1995). When tests comparing all 3 species yielded significant results, the survival of Codium fragile was compared to that of Saccharina longicruris and Desmarestia viridis in separate log-rank tests. Urchin density was compared between experimental runs using analysis of variance (ANOVA), followed by Tukey's tests. To evaluate whether differences in urchin density were partially responsible for differences in the pattern of algal survival between runs, we performed a Cox proportional hazards analysis (as described in 'Materials and methods-Expt 1') for each algal species, using urchin density as an explanatory variable. For this analysis, algae lost within the first $24 \mathrm{~h}$ of the spring run were attributed to the first regular $(\sim 4 \mathrm{~d})$ interval to avoid a potentially confounding effect of sampling regime.

To evaluate the loss of experimental thalli due to factors other than urchin grazing, we placed a single ring in a clearing within a large patch of Desmarestia viridis during each experimental run (Fig. 1c). D. viridis is chemically defended against grazing by high concentrations of sulphuric acid contained within vesicles within the thallus, and mechanically defended by a 'whiplash effect' that limits urchin distribution, movement and grazing (Himmelman 1984, Konar 2000, Gagnon et al. 2006). As a result, few urchins were found within these large patches. Urchins that penetrated the patch of $D$. viridis and that were found in the clearing were removed, and any thallus that showed obvious signs of urchin grazing was replaced.

\section{RESULTS}

\section{Survival at grazing front}

Urchin density (mean \pm SD) along the lower margin of the algal bed decreased between 30 April $\left(142 \pm 57 \mathrm{~m}^{-2}\right)$ and 16 June 2003 (28 \pm $35 \mathrm{~m}^{-2}$ ). During this period, urchins appeared to have dispersed from the front, leaving a series of smaller patches of densely aggregated urchins and scattered individuals between boulders and along the margin of the algal bed. The position of the remaining urchins and cleared substratum relative to landmarks at the site indicated that the front had advanced 1 to $2 \mathrm{~m}$ through the algal bed between these dates. The urchins had destructively grazed the kelp Saccharina longicruris and nearly all erect turf algae in this 1 to $2 \mathrm{~m}$ wide swath, leaving only encrusting coralline algae and scattered thalli of Codium fragile and Desmarestia viridis on the denuded rock substrata (Table 1). The cover of $C$. fragile and $D$. viridis did not differ significantly between the newly formed barrens and the algal bed immediately in advance of the front, indicating that they had been by-passed by the grazing front (Table 1). Both species persisted in the barrens throughout the remainder of our study.

We monitored 4 ind. of Codium fragile that were easily identifiable due to their position atop a large boulder in the barrens near the edge of the algal bed (Fig. 2). By late April, urchins had begun to remove turf algae from lower parts of the boulder, but had not yet

Table 1. Desmarestia viridis, Codium fragile and Saccharina longicruris. Comparisons of the percentage cover in video frames taken $1 \mathrm{~m}$ inside the algal bed $(n=20)$ and $1 \mathrm{~m}$ inside the barren ground $(\mathrm{n}=20)$ relative to the position of the urchin front and interface between habitats, at Birchy Head. *Welch $t$-test was used when Bartlett test $(\alpha=0.05)$ indicated that variances were unequal. Because kelp was not observed in the barrens, a 1-sample $t$-test was used to compare kelp cover in the algal bed to an expected value of zero

\begin{tabular}{|c|c|c|c|c|c|c|c|}
\hline \multirow[t]{3}{*}{ Group } & \multicolumn{4}{|c|}{- Cover $(\%)$} & \multirow[t]{3}{*}{$t$} & \multirow[t]{3}{*}{$\mathrm{df}$} & \multirow[t]{3}{*}{$\mathrm{p}$} \\
\hline & \multicolumn{2}{|c|}{ Algal bed } & \multicolumn{2}{|c|}{ Barrens } & & & \\
\hline & Mean & $\mathrm{SD}$ & Mean & SD & & & \\
\hline D. viridis & 49.2 & 6.1 & 35.9 & 18.1 & 1.81 & 38 & 0.078 \\
\hline C. fragile* & 0.7 & 0.4 & 1.6 & 5.0 & 0.74 & 23.72 & 0.47 \\
\hline S. longicruris & 1.0 & 0.4 & 0 & 0 & 2.52 & 19 & 0.021 \\
\hline Turf algae* & 47.9 & 5.9 & 2.1 & 2.6 & 7.73 & 19.36 & $<0.001$ \\
\hline Bare substrate* & 1.1 & 0.9 & 61.0 & 19.4 & 13.79 & 19.09 & $<0.001$ \\
\hline
\end{tabular}
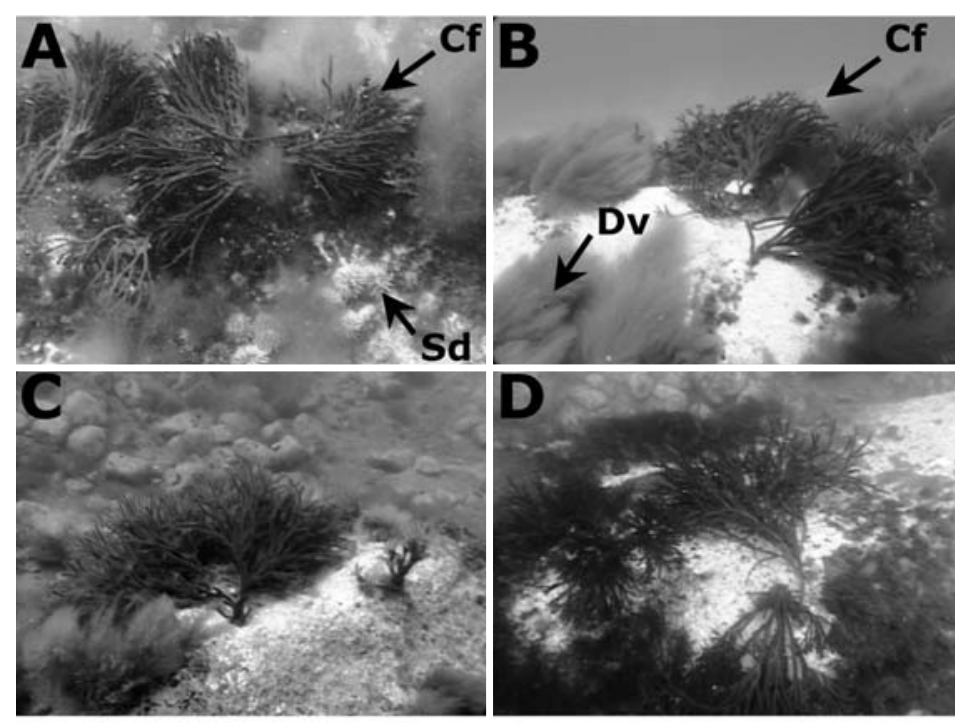

Fig. 2. Codium fragile, Desmarestia viridis and Strongylocentrotus droebachiensis. Thalli of $C$. fragile (Cf) and D. viridis (Dv) on a boulder at Birchy Head in (A) April, just before encounter by a grazing front of sea urchins $S$. droebachiensis (Sd), and following its passage, in (B) June, (C) August and (D) October 2003 
reached these thalli. By June, urchins had reached the top of the boulder, which was now devoid of all erect macroalgae except $C$. fragile and Desmarestia viridis. One of the 4 thalli of $C$. fragile was lost in early September, but there was no evidence of grazing damage. Survival of $C$. fragile in the algal bed, where urchins were absent, was $75 \%$ during September at this site (D'Amours \& Scheibling 2007).

The urchin population at Birchy Head was decimated by mass mortality following Hurricane Juan, which struck this coast on 29 September. By 18 October, when we terminated our study, few live urchins remained along the former front $\left(5.2 \pm 6.9 \mathrm{~m}^{-2}\right)$. These displayed symptoms of morbidity consistent with infection by the pathogenic amoeba Parameoba invadens (Jones \& Scheibling 1985). Disease outbreaks have been associated with increased hurricane activity along this coast, possibly in relation to advective transport of this waterborne pathogen (Scheibling \& Hennigar 1997).

\section{Expt 1: Transplantation to a high-density front}

By the end of the experiment on 18 August, only 9 of the 96 thalli of Codium fragile placed in the path of the front remained. RMANOVA showed no differences in the survival of $C$. fragile in the intact kelp bed and cleared treatment groups (Table 2, Fig. 3a). However, a more detailed analysis using a Cox proportional hazards model indicated that kelp density, along with urchin density and the initial distance of an individual plant from the urchin front at the start of the experi-

Table 2. Codium fragile. Repeated-measures analysis of variance of the percentage of thalli surviving in treatment plots with kelp intact or cleared of kelp at the front (24 July to 18 August 2005) and in the barrens (24 July to 9 August 2005) at Splitnose Point

\begin{tabular}{|lcccc|}
\hline Source & df & MS & $F$ & $p$ \\
\hline Front & & & & \\
Between plots & & & & \\
$\quad$ Treatment & 1 & 0.93 & 0.0004 & 0.98 \\
$\quad$ Error & 4 & 2214 & & \\
$\quad$ Within plots & & & & \\
$\quad$ Time & 6 & 5722 & 36.37 & $<0.001$ \\
$\quad$ Time $\times$ Treatment & 6 & 196.2 & 1.24 & 0.32 \\
$\quad$ Error & 24 & 157.5 & & \\
Barrens & & & & \\
Between plots & & & & \\
$\quad$ Treatment & 1 & 12000 & 48.00 & 0.002 \\
$\quad$ Error & 4 & 250 & & \\
$\quad$ Within Plots & & & & \\
$\quad$ Time & 1.65 & 5073 & 18.38 & 0.003 \\
$\quad$ Time $\times$ Treatment & 3.35 & 1947 & 7.06 & 0.026 \\
$\quad$ Error & 13.38 & 276 & & \\
\hline
\end{tabular}

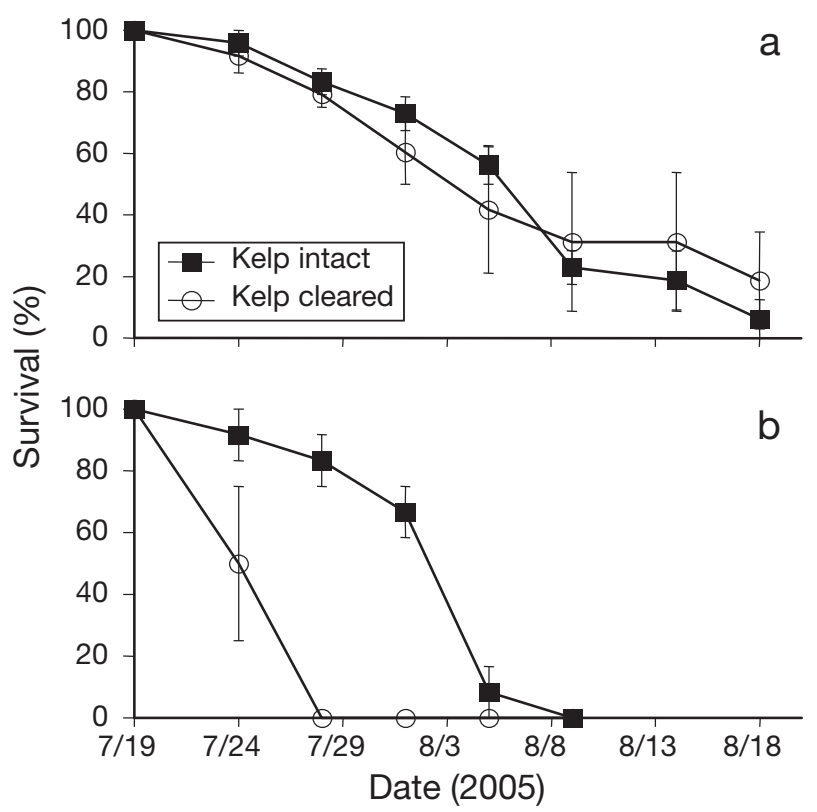

Fig. 3. Codium fragile. Survival of thalli transplanted (a) in the path of the front in the intact kelp and cleared kelp treatments or (b) in the barrens near the intact kelp canopy and cleared canopy treatments at Splitnose Point. Dates are month/day. Error bars: \pm SE

ment, all had significant effects on the survival of $C$. fragile (Tables 3 to 5). The hazard ratios indicate that the risk of mortality increased with urchin density, and decreased with kelp density and increasing distance from the front (Table 3 ). The loss of $C$. fragile generally occurred upon encounter with the leading edge of the urchin front; however, at lower urchin densities, thalli tended to survive longer following the passage of the front (Fig. 4, compare Panel a and Panel e). The percentage of transplanted thalli that survived after the front had passed decreased with mean urchin density in a plot $\left(\mathrm{r}^{2}=0.85, \mathrm{p}=0.009, \mathrm{n}=6\right)$, but was not related to the density of kelp in the plot $\left(r^{2}=0.28, p=0.28\right.$, $\mathrm{n}=6$ ). Although urchin density, kelp density and initial distance from the front influenced how long $C$. fragile survived, most individuals eventually disappeared.

Table 3. Codium fragile. Parameter estimates (b), Wald tests and hazard ratios (HR) for variables of the final Cox regression model (see Tables 4 \& 5) for the survival of thalli transplanted to experimental grids at Splitnose Point

\begin{tabular}{|c|c|c|c|c|c|c|}
\hline \multirow[t]{2}{*}{ Variable } & \multirow[t]{2}{*}{ df } & \multicolumn{2}{|c|}{$-b-$} & \multirow[t]{2}{*}{ Wald $\chi^{2}$} & \multirow[t]{2}{*}{$\mathrm{p}$} & \multirow[t]{2}{*}{ HR } \\
\hline & & Estimate & SE & & & \\
\hline Kelp density & 1 & -0.081 & 0.018 & 21.21 & $<0.001$ & 0.922 \\
\hline Urchin density & 1 & 0.016 & 0.002 & 44.72 & $<0.001$ & 1.016 \\
\hline $\begin{array}{l}\text { Initial distance } \\
\text { from front }\end{array}$ & 1 & -2.49 & 0.30 & 70.74 & $<0.001$ & 0.083 \\
\hline
\end{tabular}


Table 4. Codium fragile. Likelihood ratio (LR) statistics of models considered in the step-down variable selection procedure compared to the null model for the survival data from individuals transplanted to grids at Splitnose Point. Parameters include D: initial distance from front; U: urchin density; $\mathrm{K}$ : kelp density; and interactions

\begin{tabular}{|c|c|c|c|c|}
\hline Model & Model & LR & LR & $\mathrm{p}$ \\
\hline $\begin{array}{ll}1 & \mathrm{D}+\mathrm{U}+\mathrm{K}+\mathrm{DU}+\mathrm{DK}+ \\
& \mathrm{UK}+\mathrm{DUK}\end{array}$ & 77 & 125.9810 & 7 & $<0.001$ \\
\hline $\begin{array}{ll}2 & \mathrm{D}+\mathrm{U}+\mathrm{K}+\mathrm{DU}+\mathrm{DK}+ \\
\mathrm{UK}\end{array}$ & 78 & 125.9746 & 6 & $<0.001$ \\
\hline $3 \mathrm{D}+\mathrm{U}+\mathrm{K}+\mathrm{DU}+\mathrm{UK}$ & 79 & 125.9745 & 5 & $<0.001$ \\
\hline $4 \mathrm{D}+\mathrm{U}+\mathrm{K}+\mathrm{DK}+\mathrm{UK}$ & 79 & 125.7952 & 5 & $<0.001$ \\
\hline $5 \mathrm{D}+\mathrm{U}+\mathrm{K}+\mathrm{DU}+\mathrm{DK}$ & 79 & 125.9420 & 5 & $<0.001$ \\
\hline $6 \mathrm{D}+\mathrm{U}+\mathrm{K}+\mathrm{DU}$ & 80 & 125.9420 & 4 & $<0.001$ \\
\hline $7 \quad \mathrm{D}+\mathrm{U}+\mathrm{K}+\mathrm{UK}$ & 80 & 125.5289 & 4 & $<0.001$ \\
\hline $8 \mathrm{D}+\mathrm{U}+\mathrm{K}$ & 81 & 125.4848 & 3 & $<0.001$ \\
\hline $9 \mathrm{U}+\mathrm{K}$ & 82 & 102.9908 & 2 & $<0.001$ \\
\hline $10 \mathrm{D}+\mathrm{K}$ & 82 & 69.4738 & 2 & $<0.001$ \\
\hline $11 \mathrm{D}+\mathrm{U}$ & 82 & 20.0259 & 2 & $<0.001$ \\
\hline
\end{tabular}

Table 5. Likelihood ratio (LR) statistics of comparisons between hierarchical models in the step-down selection procedure (see Table 4). During each step the current model was compared to the nested model with 1 parameter less that had the highest LR statistic, in order to determine if the data could be adequately described with fewer parameters

\begin{tabular}{|lcccc|}
\hline Comparison & LR & df & p & Result \\
\hline 1 vs. 2 & 0.0064 & 1 & 0.94 & Drop DUK \\
2 vs. 3 & 0.0001 & 1 & 0.99 & Drop DK \\
3 vs. 6 & 0.0325 & 1 & 0.86 & Drop UK \\
8 vs. 6 & 0.4572 & 1 & 0.50 & Drop DU \\
9 vs. 8 & 22.4940 & 1 & $<0.001$ & Retain Model 8 \\
\hline
\end{tabular}

All Codium fragile transplanted into the kelp bed beyond the grids survived until the end of the experiment, while all individuals transplanted into the barrens $5 \mathrm{~m}$ from the front were lost by 9 August (Fig. 3b). In contrast to thalli placed in the path of the front, the percentage of individuals surviving in the barrens during the sampling intervals differed according to whether or not kelp was cleared from the adjacent grid in the kelp bed. Using RMANOVA, we detected a significant time by treatment interaction (Table 2). Post hoc comparisons conducted for each date indicated that significantly fewer thalli of C. fragile associated with the cleared treatment were present on 28 July and 1 August. The mean ( \pm SD) number of urchins within $30 \mathrm{~cm}$ of the transplant lines in the barrens on July 25 was 3 -fold greater in cleared $(59 \pm 27)$ than uncleared treatments $(18 \pm 9)$ (log-transformed counts, $t_{4}=2.50, \mathrm{p}=0.05$ ). There was a significant negative relationship between survival time of $C$. fragile and the number of urchins around the transplants for pooled treatments $\left(\mathrm{r}^{2}=0.27, \mathrm{p}=0.01\right)$.

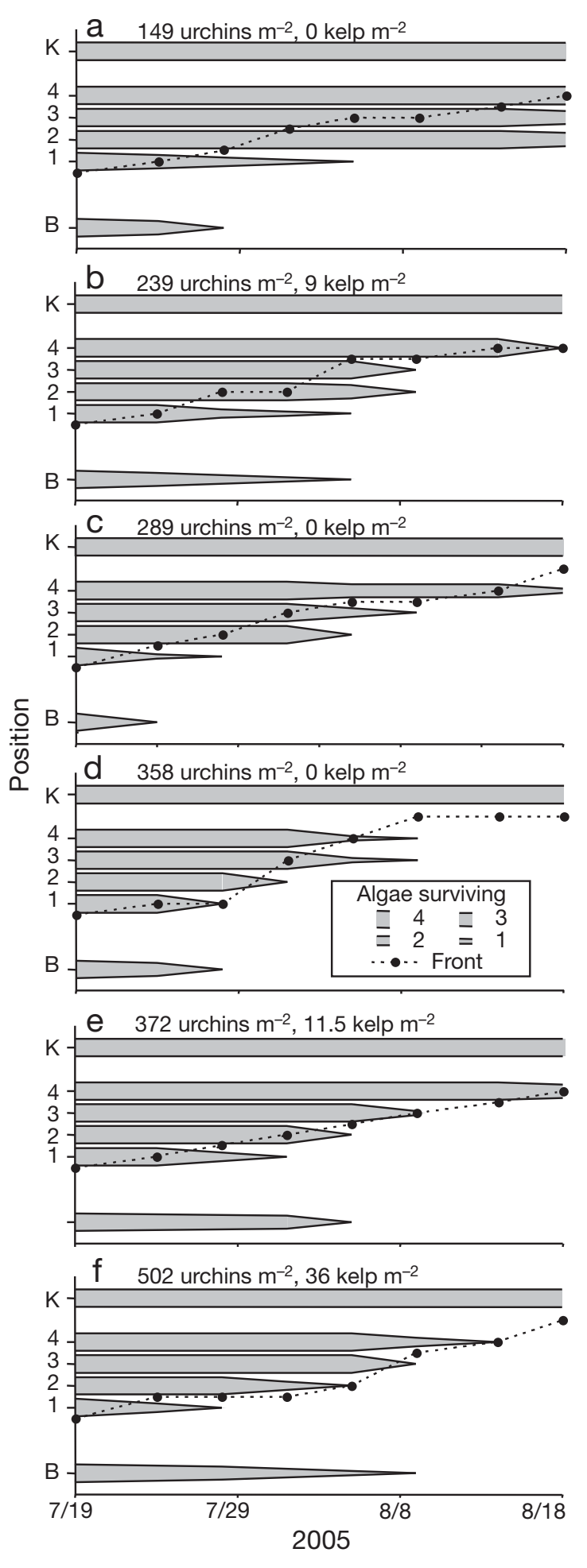

Fig. 4. Codium fragile. (a to $\mathrm{f}$ ) Position of the leading edge of the urchin front relative to positions of transplanted thalli (B: barrens line, $5 \mathrm{~m}$ into the barrens at start of Expt 1 at Splitnose Point; 1 : initially $0 \mathrm{~m}$ from front; 2 : initially $0.67 \mathrm{~m}$ from front; 3: initially $1.33 \mathrm{~m}$ from front; 4 : initially $2.0 \mathrm{~m}$ from front; K: kelp bed line, $5 \mathrm{~m}$ into kelp bed at start of the experiment) and number of thalli surviving at those positions in the 6 experimental plots 


\section{Expt 2: Survival relative to native algae in barren}

Survival times differed between algal species in all 3 experimental periods, with Saccharina longicruris being lost most rapidly (Table 6, Fig. 5). In summer 2005, all of the kelp was lost by the first sampling interval (4 d) and only 1 of 20 thalli survived beyond $4 \mathrm{~d}$ in fall 2005 and spring 2007. In spring 2007, more than half of the kelp thalli were lost after just $24 \mathrm{~h}$. We observed as many as 44 urchins, many of them feeding, in contact with an attached kelp thallus, and as many as 89 in contact with detached fragments of what appeared to be the remnants of a single kelp thallus. In contrast, we observed fewer urchins attacking Codium fragile or Desmarestia viridis at any time (up to 30 for $C$. fragile and 12 for $D$. viridis). The survival functions of $C$. fragile and $D$. viridis differed significantly in the summer and spring experiments, but not in the fall experiment (Table 6, Fig. 5). The survival curves of C. fragile in the summer and spring experiments were similar, but plants were lost much more slowly during the fall. While no $D$. viridis was lost in the shorter summer experiment, it was lost slowly in fall and more rapidly in the spring experiment. Urchin density in the barrens was significantly greater in the spring 2007 experiment (mean \pm SD: $10 \pm 8$ urchins $0.25 \mathrm{~m}^{-2}$ ) than in summer $(6 \pm 3)$ or fall $(7 \pm 3)$ experiments in 2005, which did not differ in urchin density (ANOVA, $F_{2,117}=$ 5.4, $\mathrm{p}=0.006$; Tukey's test, $\mathrm{p}<0.05$ ). Results of the Cox proportional hazards model indicated that differences in patterns of algal loss among experimental periods were related to urchin density, with the hazard ratio for each species increasing with urchin density (Table 7).

None of the algae protected within the patch of Desmarestia viridis were lost during the summer experiment. During the fall experiment, protected plants were not lost before Day 14, when the patch of $D$. viridis began to degrade, becoming an increasingly porous barrier to sea urchins. Around this time $D$.
Table 6. Codium fragile, Saccharina longicruris and Desmarestia viridis. Log-rank tests comparing the survival functions of $C$. fragile (C), S. longicruris (S) and D. viridis (D) in the barrens experiments at Splitnose Point

\begin{tabular}{|llrrr|}
\hline Period & Comparison & $\chi^{2}$ & df & \multicolumn{1}{c|}{$p$} \\
\hline Summer 2005 & CSD & 26.60 & 2 & $<0.001$ \\
& CS & 20.96 & 1 & $<0.001$ \\
Fall 2005 & CD & 4.24 & 1 & 0.039 \\
& CSD & 63.39 & 2 & $<0.001$ \\
& CS & 41.97 & 1 & $<0.001$ \\
Spring 2007 & CD & 0.66 & 1 & 0.42 \\
& CSD & 45.78 & 2 & $<0.001$ \\
& CS & 8.14 & 1 & 0.004 \\
& CD & 23.66 & 1 & $<0.001$ \\
\hline
\end{tabular}

Table 7. Codium fragile, Saccharina longicruris and Desmarestia viridis. Parameter estimates $(b)$, Wald tests and hazard ratios (HR) for Cox's regression model examining the effect of sea urchin density on the survival of algae in the barrens experiment

\begin{tabular}{|lcccccc|}
\hline Species & $\mathrm{df}$ & Estimate SE & & Wald $\chi^{2}$ & $\mathrm{p}$ & $\mathrm{HR}$ \\
& \multicolumn{7}{c}{ Es } & & & \\
\hline C. fragile & 1 & 0.43 & 0.11 & 15.49 & $<0.001$ & 1.53 \\
S. longicruris & 1 & 0.41 & 0.09 & 18.81 & $<0.001$ & 1.51 \\
D. viridis & 1 & 0.63 & 0.14 & 22.03 & $<0.001$ & 1.89 \\
\hline
\end{tabular}

viridis throughout the barrens began to show signs of bleaching, characteristic of the release of acid, and was attacked by large numbers of urchins. One thallus of Saccharina longicruris (Day 14), 1 of D. viridis (Day 35) and 2 of Codium fragile (both Day 42) were lost by the end of the fall experiment. In the early part of the spring experiment, thalli of $D$. viridis in both the protected and experimental treatments showed obvious signs of bleaching following a period of high wave action (Fig. 6). The surge forces moved the chains holding transplants along on the bottom and caused
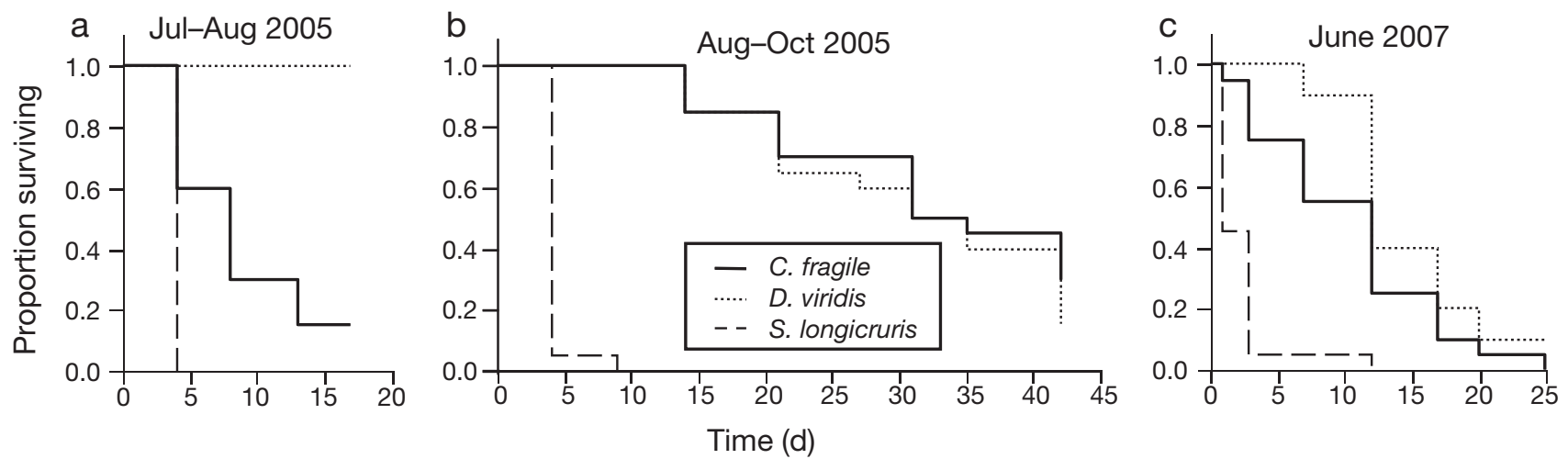

Fig. 5. Codium fragile, Desmarestia viridis and Saccharina longicruris. Survival curves of thalli transplanted into the barrens in the (a) summer, (b) fall and (c) spring runs of Expt 2 at Splitnose Point 

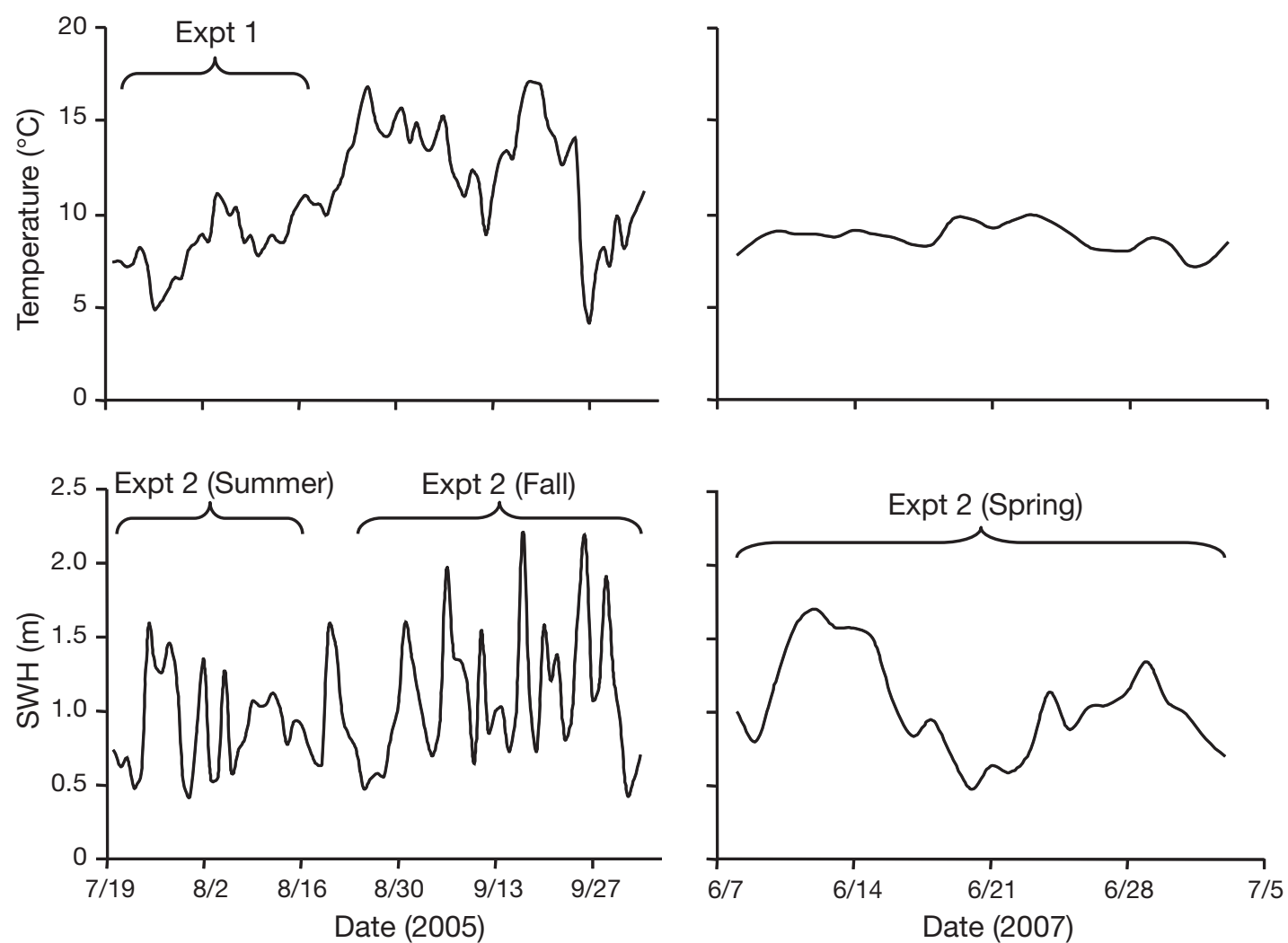

Fig. 6. Water temperature at $12 \mathrm{~m}$ at Splitnose Point and significant wave height (SWH) at the mouth of Halifax Harbour recorded during Expts 1 and 2 at Splitnose Point. Dates are month/day

some transplants of $D$. viridis to become entangled in the rope and chain. During this period, we observed increased amounts of drifting thalli of $D$. viridis in the water column and on the bottom being swept by the surge. During the last interval (Day 25) of the spring experiment, we noted the loss of 1 protected thallus of $C$. fragile and 1 of $S$. longicruris that could not be directly attributed to urchin grazing, though several urchins were found inside the patch of $D$. viridis.

\section{DISCUSSION}

We found that urchin density had an important influence on the survival of Codium fragile. Density-dependant foraging has been observed in other urchin species, with important consequences for algal community composition. Benedetti-Cecchi et al. (1998) found that consumption of filamentous algae by Paracentrotus lividus and Arbacia lixula was proportional to urchin density, while fleshy macrophytes were consumed even at the lowest urchin densities. Wright et al. (2005) suggested that a threshold density of Heliocidaris erythrogramma is required before these urchins consume the chemically defended alga Delisia pulchra. At Splitnose Point, the survival of $C$. fragile at the urchin front depended on adjacent kelp and urchin densities. Kelp biomass and urchin density strongly influence the rate of front advance (Lauzon-Guay \& Scheibling 2007b), and the loss of $C$. fragile in our experiment generally was associated with the passage of the urchin front. However, the correspondence between the arrival of the front and the disappearance of $C$. fragile was much stronger in plots with higher urchin densities. Thus, the decrease in hazard ratio for $C$. fragile at low urchin density is due not only to the slower movement of the front through the algal bed, but also a greater probability of survival of thalli once urchins have encountered them. Similarly, at Birchy Head we observed urchins approach and bypass $C$. fragile while consuming all other erect macroalgae except Desmarestia viridis. These observations suggest that urchins at lower densities exhibit a degree of selectivity, which is lost when density and intraspecific competition for available food increases.

Previous studies showed that urchins consumed Codium fragile only after kelp and turf algae were eliminated (Sumi \& Scheibling 2005). Therefore, we predicted that reducing the amount and quality of food available to urchins at the front, by experimentally removing kelp, would reduce the survival of $C$. fragile. However, we failed to detect a significant effect of 
canopy removal on mean survival of $C$. fragile in the path of the front using ANOVA. In a concurrent study at this site, Lauzon-Guay \& Scheibling (2007b) found that, following experimental reduction of kelp biomass, urchins redistributed themselves along the front according to the availability of food. As a result, the front advanced at a similar rate across a range of algal and urchin densities as an approximately linear feature. This capacity for redistribution, along with large between-plot variation in urchin density within both treatments and in kelp density in uncleared plots, may explain the nonsignificant ANOVA result. Analysis using the Cox proportional hazards model showed a significant effect of both kelp and urchin density on survival of $C$. fragile. A redistribution of urchins in and around the front also may explain their greater numbers around transplants of C. fragile in the barrens, and hence the more rapid disappearance of these transplants in plots where kelp was removed. This redistribution in response to canopy clearing is consistent with observations of individual urchin movement, which is not strongly directional and increases with decreased food availability (Dumont et al. 2006, Lauzon-Guay et al. 2006).

Although we did not detect an effect of removing kelp from our experimental plots, the presence of other algae can strongly influence the survival of Codium fragile. The clearest demonstration of this may be our use of a patch of Desmarestia viridis to protect both kelp and $C$. fragile against urchin grazing. Dense stands of another unpalatable macroalga, Agarum cribosum, can prevent the upward propagation of Strongylocentrotus droebachiensis grazing fronts, protecting other macroalgae against grazing and resulting in lower urchin density along the lower limit of algal beds (Gagnon et al. 2004). Similarly, a high cover of $D$. viridis at Birchy Head may have led to a change in urchin aggregation and feeding behaviour, which halted the advance of the front and likely contributed to the long-term survival of $C$. fragile at that site. Dense stands of $D$. viridis also have been observed at a nearby site, with coincident reductions in urchin density and feeding activity (Scheibling et al. 1999).

The patterns of survival of algal species that we transplanted to the deeper barrens largely matched our expectation. Saccharina longicruris was attacked by large numbers of urchins and tended to disappear very quickly. In contrast, Codium fragile disappeared more slowly, much of it after the loss of $S$. longicruris. C. fragile survived much longer in the fall than in the spring and summer experiments, with roughly a third of individuals surviving until the end of the fall experiment (42 d). Our results suggest that this difference is due, in part, to differences in urchin density among the 3 periods. Algae tended to be lost most rapidly in the spring experiment when urchin density was greatest. However, extended survival of $C$. fragile in the fall experiment may reflect a change in urchin behaviour in response to environmental conditions during this period. Urchin activity decreases with increased wave action, and destructive grazing is significantly reduced when SWH is $>1 \mathrm{~m}$ (Lauzon-Guay \& Scheibling 2007a). During the fall experiment, $\mathrm{SWH}$ was frequently $>1 \mathrm{~m}$ and approached or exceeded $2 \mathrm{~m}$ on 4 occasions. Water temperature also may have influenced urchin behaviour. Strongylocentrotus droebachiensis is a cold-water species and has an upper thermal tolerance limit of $22^{\circ} \mathrm{C}$ (Percy 1973, Scheibling \& Stephenson 1984). In a concurrent study, the advance of the grazing front was unusually low during periods of elevated water temperature between 26 August and 7 September, and between 18 and 22 September (Lauzon-Guay \& Scheibling 2007a). Urchin grazing in the barrens may have been similarly reduced, particularly on a less attractive food such as C. fragile. Although the survival of Desmarestia viridis in the barrens also varied greatly among seasons, increased losses of this alga were likely due to the apparent release of acid from thalli damaged by entanglement in their own anchors during the spring experiment, and the natural senescence of this annual alga in the fall (Scheibling et al. 1999).

Collectively, our results suggest that the probability that Codium fragile will survive in the face of destructive grazing fronts of urchins is greater than that of laminarian kelps or algal turfs, but somewhat less than that of Desmarestia viridis. It appears that most thalli of $C$. fragile will eventually be consumed by urchins in the front or by those trailing in the barrens. The survival of C. fragile does not appear to depend on the availability of more attractive food, at least under the conditions of our experiments, but rather on the density and behaviour of urchins, which may be modified by water temperature, hydrodynamic conditions and the presence of dense stands of unpalatable macroalgae.

Acknowledgements. The authors thank J. Lindley, J. S. Lauzon-Guay, P. Gagnon, M. Saunders, A. Schmidt, A. Pinder and D. Knip for their assistance with fieldwork. P. Gagnon, J. S. Lauzon-Guay and 3 anonymous reviewers provided valuable comments on the manuscript. This research was supported by scholarships from the Natural Sciences and Engineering Research Council, Canada (NSERC) and Killam Trust to D.A.L., and an NSERC Discovery Grant to R.E.S.

\section{LITERATURE CITED}

Allison PD (1995) Survival analysis using SAS: a practical guide. SAS Institute, Cary, NC

Benedetti-Cecchi L, Bulleri F, Cinelli F (1998) Density-dependent foraging of sea urchins in shallow subtidal reefs on the west coast of Italy (western Mediterranean). Mar Ecol Prog Ser 163:203-211 
Chapman AS, Scheibling RE, Chapman ARO (2002) Species introductions and changes in marine vegetation of Atlantic Canada. In: Claudi R, Nantel P, Muckle-Jeffs E (eds) Alien invaders in Canada's waters, wetlands and forests. Canadian Forest Service Science Branch, Natural Resources Canada, Ottawa, p 133-148

$>$ Colautti RI, Ricciardi A, Grigorovich IA, Maclsaac HJ (2004) Is invasion success explained by the enemy release hypothesis? Ecol Lett 7:721-733

D'Amours O, Scheibling RE (2007) Effect of wave exposure on morphology, attachment strength and survival of the invasive green alga Codium fragile ssp. tomentosoides. J Exp Mar Biol Ecol 351:129-142

$>$ Dumont CP, Himmelman JH, Russell MP (2006) Daily movement of the sea urchin Strongylocentrotus droebachiensis in different subtidal habitats in eastern Canada. Mar Ecol Prog Ser 317:87-89

> Gagnon P, Himmelman JH, Johnson LE (2004) Temporal variation in community interfaces: kelp-bed boundary dynamics adjacent to persistent urchin barrens. Mar Biol 144: 1191-1203

Gagnon P, St-Hillaire-Gravel LV, Himmelman JH, Johnson LE (2006) Organismal defenses versus environmentally mediated protection from herbivores: unraveling the puzzling case of Desmarestia viridis (Phaeophyta). J Exp Mar Biol Ecol 334:10-19

> Harris LG, Tyrrell MC (2001) Changing community states in the Gulf of Maine: synergism between invaders, overfishing and climate change. Biol Invasions 3:9-21

Himmelman JH (1984) Urchin feeding and macroalgal distribution in Newfoundland, eastern Canada. Nat Can 111: $337-348$

Jones GM, Scheibling RE (1985) Paramoeba sp. (Amoebida, Paramoebidae) as the possible causative agent of sea urchin mass mortality in Nova Scotia. J Parasitol 71: 559-565

Keane RM, Crawley MJ (2002) Exotic plant invasions and the enemy release hypothesis. Trends Ecol Evol 17:164-170

Konar B (2000) Seasonal inhibitory effects of marine plants on sea urchins: structuring communities the algal way. Oecologia 125:208-217

Lauzon-Guay JS, Scheibling RE (2007a) Seasonal variation in movement, aggregation and destructive grazing of the green sea urchin (Strongylocentrotus droebachiensis) in relation to wave action and sea temperature. Mar Biol 151:2109-2118

Lauzon-Guay JS, Scheibling R (2007b) Behavior of sea urchin (Strongylocentrotus droebachiensis) grazing fronts: food mediated aggregations and density dependant facilitation. Mar Ecol Prog Ser 329:191-204

Lauzon-Guay JS, Scheibling RE, Barbeau MA (2006) Movement patterns in the green sea urchin, Strongylocentrotus droebachiensis. J Mar Biol Assoc UK 86:167-174

Levin PS, Coyer JA, Petrik R, Good TP (2002) Community-wide effects of non-indigenous species on temperate reefs. Ecology 83:3182-3193

Lyons DA, Scheibling RE (2007) Effect of dietary history and algal traits on feeding rate and food preference in the green sea urchin Strongylocentrotus droebachiensis. J Exp Mar Biol Ecol 349:194-204

Editorial responsibility: Sean Connell, Adelaide, Australia
Lyons DA, Van Alstyne KL, Scheibling RE (2007) Anti-grazing activity and seasonal variation of dimethylsulfoniopropionate (DMSP)-associated compounds in the invasive alga Codium fragile ssp. tomentosoides. Mar Biol 153: 179-188

Maron JL, Vila M (2001) When do herbivores affect plant invasion? Evidence for the natural enemies and biotic resistance hypotheses. Oikos 95:361-373

Miller RJ (1985) Succession in sea urchin and seaweed abundance in Nova Scotia, Canada. Mar Biol 84:275-286

Miller RJ, Nolan SC (2000) Management of the Nova Scotia sea urchin fishery: a nearly successful habitat based management regime. Fisheries and Oceans Science, Canadian Stock Assessment Secretariat, Ottawa

Parker JD, Hay ME (2005) Biotic resistance to plant invasions? Native herbivores prefer non-native plants. Ecol Lett 8: 959-967

Parker JD, Burkepile DE, Hay ME (2006) Opposing effects of native and exotic herbivores on plant invasions. Science 311:1459-1461

Parmar MKB, Machin D (1995) Survival analysis: a practical approach. John Wiley \& Sons, Chichester

Percy JA (1973) Thermal adaptation in the boreo-arctic echinoid Strongylocentrotus droebachiensis (OF Muller, 1776). II. Seasonal acclimatization and urchin activity. Physiol Zool 46:129-136

Scheibling RE, Anthony SX (2001) Feeding, growth and reproduction of sea urchins (Strongylocentrotus droebachiensis) on single and mixed diets of kelp (Laminaria spp.) and the invasive alga Codium fragile ssp. tomentosoides. Mar Biol 139:139-146

Scheibling RE, Gagnon P (2006) Competitive interactions between the invasive green alga Codium fragile ssp. tomentosoides and native canopy-forming seaweeds in Nova Scotia (Canada). Mar Ecol Prog Ser 325:1-14

Scheibling RE, Hennigar AW (1997) Recurrent outbreaks of disease in sea urchins Strongylocentrotus droebachiensis in Nova Scotia: evidence for a link with large-scale meteorologic and oceanographic events. Mar Ecol Prog Ser 152: 155-165

Scheibling RE, Stephenson RL (1984) Mass mortality of Strongylocentrotus droebachiensis (Echinodermata: Echinoidea) off Nova Scotia, Canada. Mar Biol 78:153-164

Scheibling RE, Hennigar AW, Balch T (1999) Destructive grazing, epiphytism, and disease: the dynamics of sea urchinkelp interactions in Nova Scotia. Can J Fish Aquat Sci 56: 2300-2314

Sumi CBT, Scheibling RE (2005) Role of grazing by sea urchins Strongylocentrotus droebachiensis in regulating the invasive alga Codium fragile ssp. tomentosoides in Nova Scotia. Mar Ecol Prog Ser 292:203-212

Van Alstyne KL, Wolfe GV, Freidenburg TL, Neill A, Hicken C (2001) Activated defense systems in marine macroalgae: evidence for an ecological role for DMSP cleavage. Mar Ecol Prog Ser 213:53-65

Wright JT, Dworjanyn SA, Rogers CN, Steinberg PD, Williamson JE, Poore AGB (2005) Density-dependent sea urchin grazing: differential removal of species, changes in community composition and alternative community states. Mar Ecol Prog Ser 298:143-156

Submitted: October 11, 2007; Accepted: January 28, 2008 Proofs received from author(s): February 19, 2008 